\title{
Relation between biomimetic and functional analysis in product design methodology
}

\author{
I. Lopez Forniés \& L. Berges Muro \\ Department of Design and Manufacturing Engineering, \\ Zaragoza University, Spain
}

\begin{abstract}
The use of bionics and biomimetics in industrial design is being more and more extended. This paper has the purpose of showing how the method is not only based on bio-inspiration or bionics, considering it as a creative tool, but also views it as a complementary tool used in design methodologies. This work presents a method to establish a relationship between functional analysis and biomimetics, showing how to integrate these tools in the design process, bringing an improvement for design products with more functional and innovative casings. Time and tasks at the stage of biomimetics research are reduced by focusing on the functions that frame the innovation and finally the finding of criteria that allow us to decide whether the use of these tools is necessary. The objectives are first of all the validation of the methodology based on the use of several product design tools, then the understanding of how to apply them so as to make them complementary, aiming for greater success in the final result, and finally to establish criteria to establish product typologies, as well as solutions in nature from natural individuals using analogies to link the natural and artificial environments. The methodology is based on the selection of a product typology, the application of analogy methods between casings or product shells and natural exoskeletons in nature to carry out the functional analysis and biomimetic research, and finally the use of the design process of conceptualising, embodiment and detailing to present and evaluate the final results.
\end{abstract}

Keywords: design methods, innovation, functional analysis, biomimetic, bionic, exoskeleton, shell, casing. 


\section{Introduction}

The need for using biomimetics as a creative source for the potential shown in combination with other design methodologies has been found [1], as well as the motivation for the study of the natural environment and its adaptation to the process of product design for our artificial environment.

On the other hand, there is a critical view as to how industrial projects are developed, with no acknowledgement of nature or observation of its clever and already developed solutions [2]. Natural wisdom is offering good solutions; therefore not looking at nature for the development of functions (and therefore systems, organs, structures and materials) is limiting our possibilities of improving products [3].

Innovation could be made by detecting new functions needed by products that are similar in nature, particularly in the casing-exoskeleton relationship [4]. The great analogy between casings and exoskeletons, which has been a factor in choosing these types of products, is also worth mentioning.

In many cases biomimetic design is not applied because there is no clear methodology. For this reason, a new methodology that can be used in design projects and product development has been defined.

In this research paper, experimentation has been carried out on design methods in various projects, and the possibility of establishing a new methodology by researchers has been achieved [5].

Nowadays biomimetics have been developed in military technology, medical products, robotics, and so on. As an example, functional characteristics related to insects have been found in exploring robots as a strong source of inspiration due to their arthropod feature.

\section{Objectives}

The main objective focuses on the development of the design methodology basis for casings from the biomimetic perspective. This methodology will help designers to detect solutions developed by nature and others that can satisfy product needs in a better way in order to achieve innovation [6-7].

Some other objectives are:

- To find out, analyze, and get to know existing methodologies related to biomimetic analysis, and also to relate them to some other analyses used in product design, such as functional, formal, structural, materials or usage analysis.

- To learn from nature's solutions in order to create products that are respectful towards the natural environment.

- To establish valid sources of information that contribute knowledge in the various analyses carried out in the design process.

- Working with these methods the designer will be familiar with the information research, because some key functions and natural solutions are needed.

To obtain these objectives a product design or a new concept with functional improvements in the casing is proposed to be developed. 


\section{Methodology}

To achieve the main objective of this research paper, evaluation of the methodology is carried out in order to propose a new work structure in which some actions are needed before the design stage, see table 1 . In this previous stage the functional requirements are established in order to obtain the improvement and innovation in the product, thus drawing a framework for the project. From previous experiences it is known that biomimetics can give project arguments and solutions for the problems proposed.

\subsection{Pre-initial phase: setting the framework}

An initial situation is proposed in which there is no assignment or a project with specific objectives, so it is necessary to create a framework that sets out the main criteria for selecting the design object. This framework will be called "projecting argument".

In our example, consuming product casings are taken due to the fact that they are contained in virtually all products. In some cases casings serve little purpose but their presence is absolutely necessary, their functionality being able to extend. On the other hand, there are products containing only their casing that have all the functions, on which improvements or innovations might be proposed.

In addition, the "biomimetic argument" that there should be a relationship with the argument projecting justified by analogies is also defined, looking for analogous natural solutions that match to similar problems in our product.

Table 1: $\quad$ Main project structure.

\begin{tabular}{|l|c|c|c|c|c|c|}
\hline phase & Pre-initial & 1 & 2 & 3 & 4 & 5 \\
\hline activity & $\begin{array}{c}\text { Setting the } \\
\text { framework }\end{array}$ & $\begin{array}{c}\text { Analyzing } \\
\text { the key } \\
\text { functions }\end{array}$ & $\begin{array}{c}\text { Looking for } \\
\text { biomimetics }\end{array}$ & $\begin{array}{c}\text { Applying } \\
\text { biomimetics to } \\
\text { key functions }\end{array}$ & $\begin{array}{c}\text { Concept } \\
\text { design }\end{array}$ & $\begin{array}{c}\text { Embodiment } \\
\text { design }\end{array}$ \\
\hline
\end{tabular}

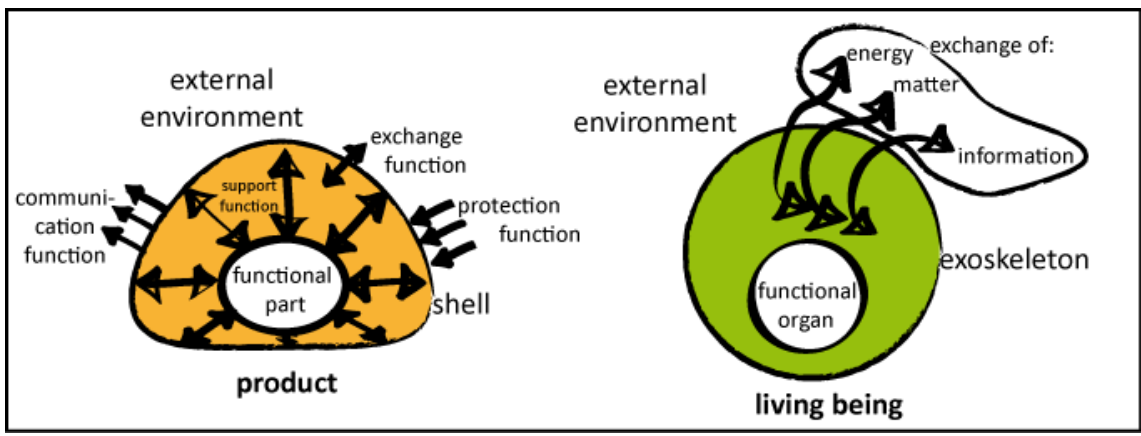

Figure 1: The relationship of a product and a living being to the external environment through the shell and the exoskeleton. 
Figure 1 shows how both the natural and man-made object are related internally and externally with their environment and how the exoskeleton and housing behave. The living being is characterized by the exchange of energy, matter and information; however, the product is characterized by its functions. Its casing provides protection and support, allows the exchange of matter and energy and allows communication. In both cases they are basic functions.

Exoskeletons are taken as regards biomimetic. They are the housing of animals and some plants. Invertebrates comprise the most diverse animal group on earth and represent over $90 \%$ of the planet life forms, so their exoskeletons include a large number of functions, some of them are basic and fundamental; others are specific and have a strong differentiation that will make them special for our study.

\subsection{Phase 1: analyzing key functions}

It is in this part of the project where functional analysis is applied creatively in search for innovation, there is no physical object in which functions are analyzed, but new or improved ones are being searched for.

As there are many options for a project development, a way is established to define and label it. First of all a list is made of potential products in which the housing is a predominant factor due to its functionality and physical factors such as weight, volume, material in relation to the function performed, etc. ... This list of 10 to 15 objects and/or products is ordered, and 3 to 4 products are chosen, those that may have more chances to find innovative features, to create mental maps.

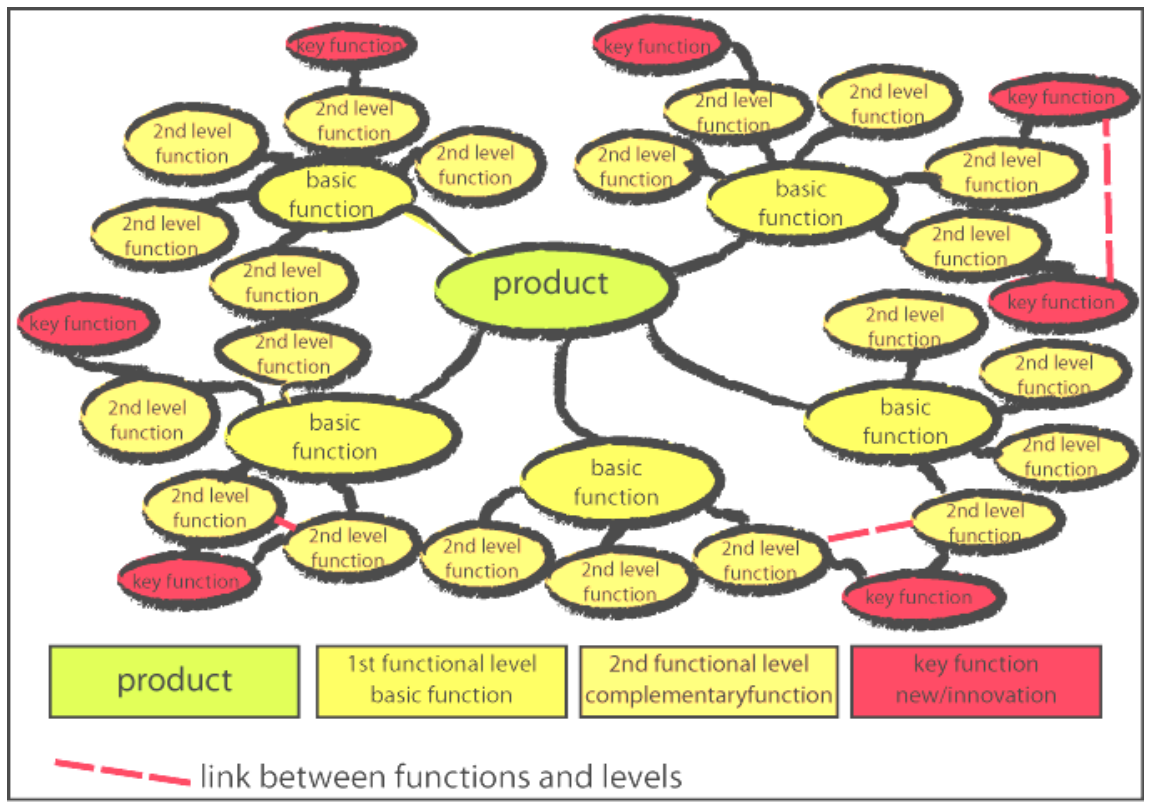

Figure 2: $\quad$ Key function hierarchy in mind maps. 
In this first phase mind maps are used to detect "key functions", which later will be related to the solutions of the natural environment. Functional analysis is carried out using the technique of mind map, as a creative way to organize and rank ideas that may arise as functions rather than other techniques in which the object must be present in order to be analyzed.

Levels are established from the most generic functions to the most specific ones. The basic functions give rise to other functions in which a target or feature that differentiates the product is more specifically defined. To reach functions that are critical and that have not been developed yet, these key functions will be the germ of a possible innovation [8].

In some cases the functions are related to different levels and between different functional groups, Figure 2 shows with dashed lines the relationships that may have a greater interest. Those functions that are not related to biomimetic argument are discarded, thereby avoiding the development of alternatives outside the defined framework.

\subsection{Phase 2: looking for biomimetics}

Once the key functions have been defined, the research phase begins, conducted in parallel, the project is first documented with the state of the art, looking for more innovative objects by analyzing the reasons that differentiate them. On the other hand, biomimetic research, in which the way the exoskeletons perform key functions is search for, is developed. Searches are performed by identifying the sources of valid information, setting search criteria, and arranging information [9]. Along with the analysis of information, a table of analogies between needs and solutions is displayed. Sources are often specific documentation from specialists, biologists, scientists and researchers in science museums, and databases such as ASK-Nature.org among others [10].

To develop the bionic research phase a method is applied in setting up a table with three columns, the first column with the key functions that are our goals, the second one with the research lines that relate to ways of achieving the objectives, and the third one in which each of these lines relate to a living being that can do

Table 2: $\quad$ Finding biomimetic references for key functions.

\begin{tabular}{|c|c|c|}
\hline $\begin{array}{c}\text { KEY FUNCTION } \\
\text { (PROJECT OBJECTIVES) }\end{array}$ & $\begin{array}{c}\text { RESEARCH GUIDELINES } \\
\text { (HOW TO ACHIEVE THE KEY FUNCTIONS) }\end{array}$ & $\begin{array}{l}\text { NATURAL REFERENCE } \\
\text { (BIOMIMETIC RELATION) }\end{array}$ \\
\hline \multicolumn{2}{|l|}{ KEY FUNCTION 1} & LIVING BEING 1 \\
\hline & jvVRU CUULU...: & |LIVING BEING 2 \\
\hline & WHY SHOULD...? & LIVING BEING 3 \\
\hline & WHAT STRUCTURE COULD...? & LIVING BEING 4 \\
\hline & WHAT MATERIAL COULD....? & LIVING BEING 5 \\
\hline KEY FUNCTION 2 & QUESTIONS FOR KEY FUCNTION 2 & LIVING BEING $\mathrm{x}$ \\
\hline KEY FUNCTION 3 & QUESTIONS FOR KEY FUCNTION 3 & LIVING BEING y \\
\hline KEY FUNCTION 4 & QUESTIONS FOR KEY FUCNTION 4 & LIVING BEING z \\
\hline
\end{tabular}


it in a particular way. Table 2 shows an example of how to develop the table to find biomimetic reference.

The table presents a two-way path in which issues like getting the key functions and who is closed in nature to our need, shown by the orange line. Once found a series of natural reference, points are chosen to implement their function or way of life to our goal, shown by the green line.

\subsection{Phase 3: applying biomimetics to key functions}

In this phase more valid biomimetic references relate with the key function, and there is an analogy development of bionics in the opposite direction toward the solution applicable to the product, perhaps this is the most conceptual phase for defining the product and how it will be developed.

The development usually requires a series of the natural solution upgrading to be applied on the product. Table is used in the opposite direction, shown in Figure 3 table by the green line, and the references found in nature are transformed and adapted to be a solution for key functions, which will be transformed into product requirements, adding value and differentiation and thus generating innovation.

Innovation is sometimes incremental due to a simple but novel functional improvement. However, there are cases where the innovation is radical since project results finally find new product concepts.

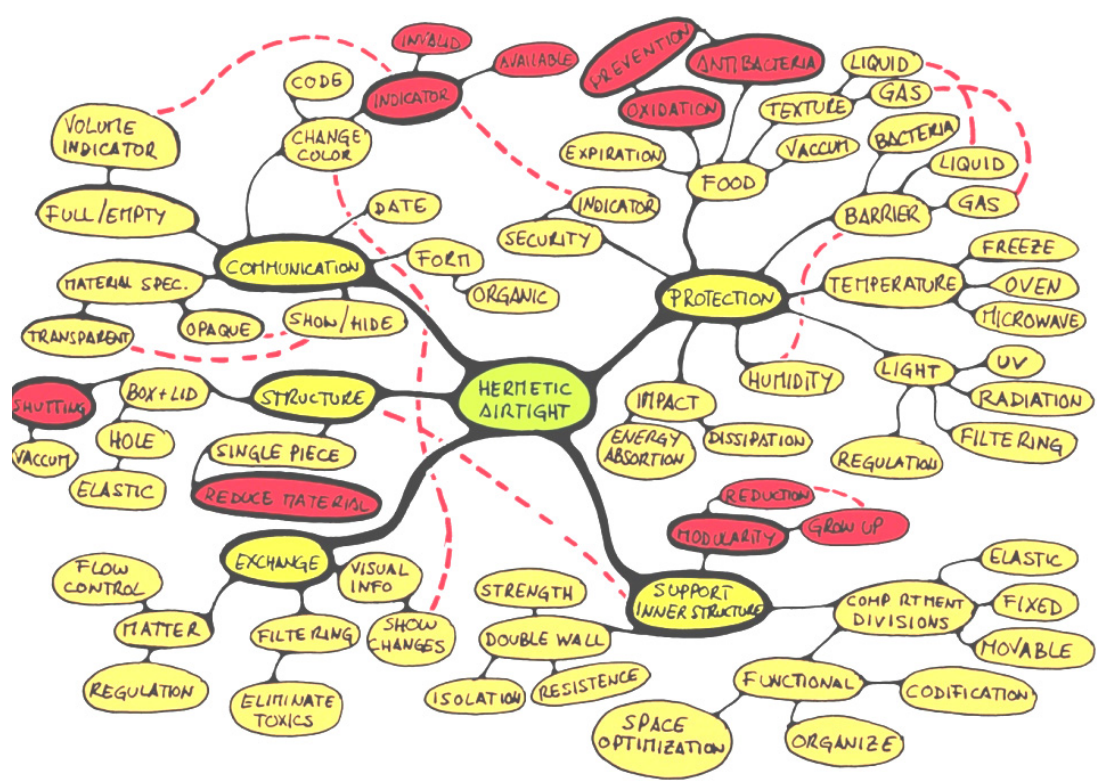

Figure 3: Mind map for an airtight/hermetic, showing relations between levels and key functions. 


\subsection{Phase 4: concept design}

At this stage, conceptual design is carried out for the chosen product, research results are obtained from functional analysis and the biomimetic concept is applied into a redesign or a new product concept, establishing the improvements. The key functions determine design specifications for generating various concepts. In this phase possible solutions for the conceptual design are proposed.

\subsection{Phase 5: embodiment design}

This phase will develop the embodiment design, similar to other design projects. The product dimensional level, production process, material selection, etc. take place. It has not been developed in this paper, since the projects were proposed only at the conceptual level, assessing their feasibility knowing the state of the art and the possibility of applying biomimetic results.

\section{An application example}

The pre-initial phase in which the biomimetic and projecting argument is determined has been previously defined. In the case study a reference is made to the exoskeletons in living beings and the casings in consumer products.

At the beginning of the first phase a list is made of possible products in which the casings have relevance due to their function or an outstanding feature. Products are chosen in this list regardless of their end user or environment; therefore there is no limitation for this type of specification. The list is as follows:

- Toys in general, for the water, psychomotor-like stackable or inset, animal figures, etc...

- Electronic devices with functional covers, touch, etc...

- Watertight, containers for household, professional, industrial, etc...

- Litter bins or recycling bins

- Packaging for food, disposable packs

- Products for baths, baby bathtubs, sinks, toilets, etc...

- Items or protective casings for vehicles as nut-covers, hubcaps, trims, fenders or bumpers, etc...

- Elements for body protection, helmets, bicycle or motorcycle armour, gloves, boots, goggles and masks, etc...

- Pots and planters for plants

- Suitcases and travel bags

- Coolers, refrigerators and freezers

- Cases, jewel boxes, safes

- Tents, tarpaulin, etc...

- Elements of transporting cargo, containers, trolleys, etc...

In the second phase we look into this product group for functions which can be innovative and provide differentiation and added value. The lists of functions allow us to classify and establish criteria for choosing some of them and identify key functions. 
The key functions are those that meet the functional requirements of the product, both in its main characteristic features and in the secondary or complementary functions, the objective is to find performance criteria that can correspond to functions in the natural environment.

The search for these key functions is performed by functional analysis, in our case this analysis is completed, ordered and prioritized through mind maps, started from basic functions and concluded in key functions. Mind maps are used instead of the classic technique, the functions tree, for giving greater creative freedom to be analysing an object or product that does not exist yet. The schema or functional tree is used to analyze and compare real products that can be operated.

Some of these functions are selected for biomimetic research, carried out intuitively due to the difficulty of establishing a valid criterion. In Figure 3 the mind map technique is shown with an example in which some key functions have been selected.

Before designing or creating an object one must consider what it would be if it were a living being, how nature would perform a specific function, or who in nature can be compared because they have similar functions.

After choosing the key functions these are transferred to the table in which relations with the natural environment are set, establishing a series of questions raised to reach the key function, and thus to the project objective.

The table set out various alternatives for the same key function that are chosen to be developed. The criterion for selection is based on the possibility of developing and implementing the product, looking for the viability of the key role. Figure 4 shows the table used in the example [7, 11-14].

After analyzing the table, some natural references that are interesting to generate concepts have been seen; concepts can be raised by a single natural reference or as the combination of several ones. Concepts are described as a group of product specifications and the natural reference must be transformed to be a design specification, so the biomimetic finding will be adapted to the key function. The adaptation will be done by developing ideas for the new product by means of sketches, drawings, text explaining the concept and other techniques.

As an example we explain how to use the abductor muscle of clams or mussels as a muscle-tendon between the cup and the lid, normally open when we put a piece of rubber close to the joint, the rubber force the lid to open and some force is needed to close the lid, and normally closed when the cup and the lid are attached by elastic rubber far from the joint. For that example we can start to work and develop reliable and feasible solutions, sketching forms, dimensioning both parts and selecting the suitable material, as in the embodiment phase of a normal design project.

Some other ideas we have chosen for the airtight are:

- The use of the adhesive tape based on the insect's hairs as the closer of the lid.

- The use of an elastic lip all around the lid contour like the limpet to increase adhesion. 


\begin{tabular}{|c|c|c|}
\hline $\begin{array}{l}\text { KEY FUNCTION } \\
\text { (PROJECT } \\
\text { OBJECTIVES) }\end{array}$ & $\begin{array}{c}\text { RESEARCH GUIDELINES } \\
\text { (HOW TO ACHIEVE THE KEY } \\
\text { FUNCTIONS) }\end{array}$ & $\begin{array}{l}\text { NATURAL REFERENCE } \\
\text { (BIOMIMETIC RELATION) }\end{array}$ \\
\hline Avoid oxidation & $\begin{array}{l}\text { - Formation of a barrier to } \\
\text { temperature and humidity } \\
\text { - Formation of a barrier to gases, } \\
\text { liquids or solids. } \\
\text { - Elimination of oxygen 2-way valve } \\
\text { - Filter to light / UV light use, light as } \\
\text { an antibacterial agent } \\
\text { - Use of antioxidants }\end{array}$ & $\begin{array}{l}\text { - Insect exoskeletons material's } \\
\text { provide a barrier } \\
\text { - Exoskeleton's structure and } \\
\text { material provides it } \\
\text { - } \mathrm{O}_{2} \text { concentration control } \\
\text { - elimination of bacteria by UV light } \\
\text { - insert in acid medium, fragrant } \\
\text { Olive (Osmanthus fragans) }\end{array}$ \\
\hline $\begin{array}{l}\text { Antibacterial } \\
\text { behaviour }\end{array}$ & $\begin{array}{l}\text { - antibacterial surface } \\
\text { - Woven / antibacterial materials } \\
\text { - antiseptic, antibiotic and antifungal }\end{array}$ & $\begin{array}{l}\text { - Shark skin, sharklet plastic film } \\
\text { - Red and green algae (kelp) } \\
\text { - leaf-cutter ants of genus Atta (atta, } \\
\text { eciton or quisonde) its jaw sutures } \\
\text { and disinfects using formic acid }\end{array}$ \\
\hline sign/indicator & $\begin{array}{l}\text { - Detection of toxins } \\
\text { - Show a change of colour, shape, } \\
\text { texture, etc. }\end{array}$ & $\begin{array}{l}\text { - Clam, used as biological warning by } \\
\text { their sensitivity to water-soluble } \\
\text { toxic in very small concentration, is } \\
\text { closed and goes hermetic. VT } \\
\text { Aquaculture No. } 6 \text { 2nd quarter } \\
\text { 2009, notebooks OPTI } \\
\text { octopus, cuttlefish or squid's skin }\end{array}$ \\
\hline $\begin{array}{l}\text { Minimal use of } \\
\text { material }\end{array}$ & $\begin{array}{l}\text { - } \text { resistant structures with little } \\
\text { material } \\
\text { - elastic structures, the volume and } \\
\text { surface area are related and varies } \\
\text { according to the content } \\
\text { - Formally gives sensation of } \\
\text { minimum }\end{array}$ & $\begin{array}{l}\text { - virus (Shell is minimum free energy } \\
\text { structure, virus icosaedro) } \\
\text { ase of chitin (seldom used as } \\
\text { artificial material despite being } \\
\text { easy to synthesize a polymer) } \\
\text { abdomen of insects and their } \\
\text { muscle groups, such as beating of } \\
\text { the wings of a fly, internal } \\
\text { contractions of the exoskeleton, } \\
\text { exoskeleton elasticity in } \\
\text { dragonflies } \\
\text { Honeypot Ant, food fills his } \\
\text { abdomen like a balloon and carries } \\
\text { it to the anthill } \\
\text { Dragonflies, butterflies, small } \\
\text { volume for a big area }\end{array}$ \\
\hline $\begin{array}{l}\text { Growing / } \\
\text { changing form }\end{array}$ & $\begin{array}{l}\text { - Make Modules, union of several } \\
\text { elements } \\
\text { - Make elastic / inflatable / } \\
\text { deformable } \\
\text { - Format change }\end{array}$ & $\begin{array}{l}\text { - Colonies of bacteria (Shell is } \\
\text { minimum free energy structure, } \\
\text { virus icosahedron) } \\
\text { - octopus, worms, snakes } \\
\text { - Honeypot Ant } \\
\text { - OvOTECA (insect egg pouch) } \\
\text { - Pouch stores seed: Clark's } \\
\text { nutcracker throat } \\
\text { - Moult of the exoskeleton in insects. } \\
\text { - Pancake Tortoise Shell changes } \\
\text { shape " }\end{array}$ \\
\hline
\end{tabular}

Figure 4: Key functions related to biomimetic references. 


\begin{tabular}{|c|c|c|}
\hline $\begin{array}{l}\text { KEY FUNCTION } \\
\text { (PROJECT } \\
\text { OBJECTIVES) }\end{array}$ & $\begin{array}{l}\text { RESEARCH GUIDELINES } \\
\text { (HOW TO ACHIEVE THE KEY } \\
\text { FUNCTIONS) }\end{array}$ & $\begin{array}{l}\text { NATURAL REFERENCE } \\
\text { (BIOMIMETIC RELATION) }\end{array}$ \\
\hline Locking/fastener & $\begin{array}{l}\text { - suction cup to the vacuum / suction } \\
\text { - elastic lip that fits the contour } \\
\text { - adhesive (removable) } \\
\text { - Insects, dry adhesives }\end{array}$ & $\begin{array}{l}\text { - clams, bivalves, ladybugs, etc, ... } \\
\text { - clams, bivalves, razors (closed by } \\
\text { the mantle which is sensitive to } \\
\text { adverse environmental conditions, } \\
\text { the muscle contracts it pulls on the } \\
\text { ligament and resilio itself will go to } \\
\text { relax the muscle) } \\
\text { - Octopus / limpet (lapa) / leech } \\
\text { - Limpet (lapa) } \\
\text { - mussels (blue mussels / green } \\
\text { mussels) } \\
\text { - Hoverfly (Eristalis pertinax) hairs on } \\
\text { the legs of some flies. Max Planck } \\
\text { Institute. Adhesive tapes/ surfaces }\end{array}$ \\
\hline
\end{tabular}

Figure 4: Continued.

- The use of an elastic cup that fits different amount of food with the less amount of air like the honey pot ant, the egg sac or very elastic exoskeletons like the dragonfly.

- The use of deployable structures in order to keep the elastic cup in various positions, fitting different volumes like dragonflies and butterflies that change the surface/volume ratio.

- The use of the sharklet film or a similar texture in the surface to avoid bacteria.

All these ideas can be combined to create concepts that accomplish with the key functions.

\section{Evaluation and study results}

Evaluation criteria that help us to assess the findings and test the usefulness of the methodology are established. Criteria for evaluating the study are: to establish the key functions, to find biomimetic references, and finally to apply the natural solution to the key function in an innovative way.

A few design projects with common objectives have been developed, all of them need to show the relation between the natural and man-made environments through existing functions in exoskeletons and casings.

Results vary greatly due to the degree of definition, the validity of the information gathered and the complexity of the subject developed. Most of the projects achieved the objectives, both raising the key functions and searching for innovative functions in the biomimetic research.

Some of the projects had a few difficulties in the process of gathering relevant information to solve the key functions, so the need for a specialist like a biologist is evident. We found that some biomimetic referents were difficult to adapt as a product requirement. 


\section{Conclusions}

The first conclusion relates the level of innovation to the difficulty of solving the key function sought, the greater the innovation sought the greater the difficulty of finding a natural relation to provide a response to more demanding key functions. Small improvements and innovations are easier to achieve, since finding the biomimetic referents and the key role is simpler [15].

The solution in nature openly define the key function, generating design specifications, so more of a design solution is set for further development and application. Some natural references are found in invertebrates during biomimetic research but not all of them; this means that the relation between exoskeletons and casings is not exclusive because some key functions can be solved by another living group.

Another finding observed is that many of the popular applications already developed are directed towards the study and application of materials to design, while our work is directed towards the improvement of product features, this makes it difficult to obtain biomimetic solutions. To overcome this difficulty work is proposed in the second phase with biologists and specialists who know the ways of life, their roles, their behaviour and characteristics that allow us to develop our solution, an example would be the improvement of vertical hydraulic systems based on the circulatory system of a giraffe.

As methodological experimentation projects are not intended to carry out research on biologic aspects. All research and search for alternatives is based on how to apply current knowledge of biology, life forms, etc ... to the needs expressed in the objects we design.

Experimenting with design methodologies that rely on biological research results sometimes produces unknown and unresolved lines of product development which are unfeasible or require experts to raise those solutions. The product has conceptually designed improvements or innovations at a functional level and their solving based on nature, but to prove its viability remains to be proven and is part of the product development phase.

\section{References}

[1] Viñolas i Marlet, Joaquim. Diseño ecológico: hacia un diseño y una producción en armonía con la naturaleza. Blume, Barcelona, 2005

[2] Benyus, Janine. Biomimicry: innovation inspired by nature, Harper Collins Publishers Inc., New York, 1997

[3] Yoseph Bar-Cohen. Biomimetics: mimicking and inspired-by biology. Proceedings of the SPIE Smart Structures Conference, San Diego, CA., SPIE Vol. 5759-02, March 7-10, 2005

[4] Vincent J, Bogatyreva O, Bogatyrev N, Bowyer A, Pahl A. Biomimetics its practice and theory. Interface Journal of Royal Society, 2006.

[5] Andrés-Hernando, Valencia Escobar. Experimentación objetiva, un instrumento para innovar. Encuentro Latinoamericano de Diseño, Acta ${ }^{\circ} 9$, Universidad de Palermo, Buenos Aires. Argentina, 2010 
[6] Bar-Cohen Y. Biomimetics: Using nature as an inspiring model for human innovation, Bioinspiration \& Biomimetics, March 2006

[7] Hui-I Wen, Shu-jun Zhang, Kevin Hapeshi, Xiao-feng Wang. An Innovative Methodology of Product Design from Nature. Journal of Bionic Engineering 5, 2008

[8] Olga Bogatyreva, Anja-Karina Pahl, Adrian Bowyer, Julian Vincent, Data gathering for putting biology in TRIZ. Altshuller Institute 5th TRIZ Conference. Philadelphia, USA, 2003

[9] Wilson Kindlein Junior, Andrea Seadi Guanabara. Methodology for product design based on the study of bionics. , Materials and Design 26, 2005

[10] Vincent J. Biomimetic modelling. Phil. Trans R. Soc. Lond. B, 358, 15971603,2003

[11] Vogel, Steven. Comparative biomechanics, Life`s physical world, Princeton University Press, New jersey, 2003

[12] Vogel, Steven. Ancas y palancas, mecánica natural y mecánica humana. Tusquets Editores, Barcelona, 2000

[13] Wasenberg, Jorge. La rebelión de las formas. Tusquets Editores, Barcelona, 2004

[14] Biomimetics: strategies for product design inspired by nature - a mission to the Netherlands and Germany. DTI GLOBAL WATCH MISSION REPORT. JANUARY 2007

[15] JFV Vincent. Stealing ideas from nature. In Deployable Structures ed S Pellegrino. Springer, Vienna, pp. 51-58. 1997 